\title{
SUSPECT OTHERS
}

\author{
Spirit Mediums, Self-Knowledge, and Race \\ in Multiethnic Suriname
}

Suspect Others explores how ideas of self-knowledge and identity arise from a unique set of rituals in Suriname, a post-colonial Caribbean nation rife with racial and religious suspicion. Amid competition for belonging, political power, and control over natural resources, Surinamese Hindus and Ndyuka Maroons look to spirit mediums to understand the causes of their successes and sufferings and to know the hidden minds of relatives and rivals alike. Although mediumship promises knowledge of others, devotees also engage with mediums to learn about their own identities, thereby turning interpersonal suspicion into doubts about the self.

Through a rich ethnographic comparison of the different ways in which spirit mediums and their devotees navigate suspicion, Suspect Others shows how present-day Caribbean peoples come to experience selves that defy concepts of personhood inflicted by the colonial past. Stuart Earle Strange investigates key questions about the nature of selfknowledge, religious revelation, and racial discourse in a hyper-diverse society. At a moment when exclusionary suspicions dominate global politics, Suspect Others elucidates self-identity as a social process that emerges from the paradoxical ways in which people must look to others to know themselves.

\section{(Anthropological Horizons)}

STUART EARLE STRANGE is an assistant professor of anthropology at Yale-NUS College. 


\section{ANTHROPOLOGICAL HORIZONS}

Editor: Michael Lambek, University of Toronto

This series, begun in 1991, focuses on theoretically informed ethnographic works addressing issues of mind and body, knowledge and power, equality and inequality, the individual and the collective. Interdisciplinary in its perspective, the series makes a unique contribution in several other academic disciplines: women's studies, history, philosophy, psychology, political science, and sociology.

For a list of the books published in this series see p. 283. 


\section{Suspect Others}

Spirit Mediums, Self-Knowledge, and Race in Multiethnic Suriname

\section{STUART EARLE STRANGE}


(C) University of Toronto Press 2021

Toronto Buffalo London

utorontopress.com

Printed in the U.S.A.

ISBN 978-1-4875-0970-5 (cloth) ISBN 978-1-4875-0972-9 (EPUB)

ISBN 978-1-4875-4026-5 (paper) ISBN 978-1-4875-0971-2 (PDF)

Anthropological Horizons

\section{Library and Archives Canada Cataloguing in Publication}

Title: Suspect others : spirit mediums, self-knowledge, and race in multiethnic Suriname / Stuart Earle Strange.

Other titles: Spirit mediums, self-knowledge, and race in multiethnic Suriname.

Names: Strange, Stuart Earle, author.

Series: Anthropological horizons.

Description: Series statement: Anthropological horizons | Includes bibliographical references and index.

Identifiers: Canadiana (print) 20210171278 | Canadiana (ebook) 20210171545 | ISBN 9781487509705 (cloth) | ISBN 9781487540265 (paper) | ISBN 9781487509712 (PDF) | ISBN 9781487509729 (EPUB)

Subjects: LCSH: Channeling (Spiritualism) - Social aspects - Suriname. LCSH: Mediums - Suriname. | LCSH: Self-perception - Suriname. | LCSH: Suspicion - Suriname. | LCSH: Suriname - Religious life and customs. | LCSH: Suriname - Ethnic relations. | LCSH: Suriname - Race relations.

Classification: LCC BF1242.S75 S87 2021 | DDC 133.9/109883 - dc23

University of Toronto Press acknowledges the financial assistance to its publishing program of the Canada Council for the Arts and the Ontario Arts Council, an agency of the Government of Ontario.

Canada Council for the Arts
Conseil des Arts du Canada

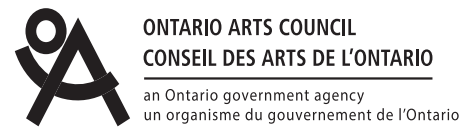


Dedicated to Sa Emma Losa, Da Sudeng African, and Kissoondial Sewpersad 
This page intentionally left blank 